JAPMAI Vol. 1, No. 1, September 2018, pp: 35 - 42
Journal of Applied Philosophical Management
and Innovation
https://journal.apmai.org/v2/index.php/japmai

\title{
BLACKWATER PURIFICATION USING SAND FILTER
}

\author{
Lies K. Wulandari ${ }^{\bowtie}$, Munasih
}

\section{Article's history}

Received July 21, 2018 Revised August 1, 2018 Accepted September 2, 2018

Key words:

Blackwater, sand filter, turbidity

\begin{abstract}
This study aimed to determine the effect of the thickness of the sand filter and the best residence time for water purification. The type of sand used in this study was concrete sand, and the observation was focused on turbidity (NTU) parameter. Measurements of turbidity were performed before treatment, as well as at each retention time from 1 to 9 days. The method of data analysis was Linear Regression analysis on SPSS 21 program. Blackwater was collected in the morning and afternoon, and the turbidity of each sample was 1000 and 800 NTU, respectively. Wastewater turbidity was continued to decreased along with the longer retention time. The best results were obtained from the treatment 3 (sand filter $20 \mathrm{~cm}$ ) with 9 days retention time, in which the turbidity levels decreased to $90 \mathrm{NTU}$ (morning sample), and $105 \mathrm{NTU}$ (afternoon sample).
\end{abstract}

Lies K. Wulandari, Munasih Civil Engineering Program, National Institute of Technology,

Malang - Indonesia

$\triangle$ Corresponding author: lieskwulandari@gmail.com

\section{Introductions}

One of the effects of population growth is the increase of clean water needs. Clean water is used by humans to conduct daily production and consumption, such as industrial activities, agriculture, livestock, cooking, washing, bathing, and many more. Any activities of production and consumption of clean water by humans cannot be separated from the residue or the waste of these activities that can no longer be utilized. The increasing amount of wastewater from domestic activities is often not supported by the provision of balanced environmental sanitation infrastructures. According to Mukhtasor (2007), wastewater requires adequate treatment as it can generate serious problems for both environmental and human health. Wastewater can also contaminate the source of raw water that supposed to used to meet the daily needs.

Communal wastewater treatment (IPAL) Tlogomas, at Malang City is one of the pilots of domestic waste processing in Indonesia and even abroad. IPAL Tlogomas is operated openly by collecting public wastewater in a container pipe which is then channeled into the main tub. The next process is through the fecal tank and then through the filtration process at the pools of purification. Pools contain aquatic plants, such as Water Hyacinth and Pandanus that serves to absorb the odor from the evaporation. However, the location is still having a bad odor.

Nowadays, many people use domestic wastewater directly as irrigation water, although the condition is not necessarily in accordance with the purpose. Blackwater must be processed so that the quality of can be increased and can be reused irrigation water. To meet the 
quality standard of wastewater disposal, it is necessary to process the wastewater optimally. This research uses concrete sand as the filter material. Concrete sand is the easiest material to obtain because it is one of the main materials in construction activities.

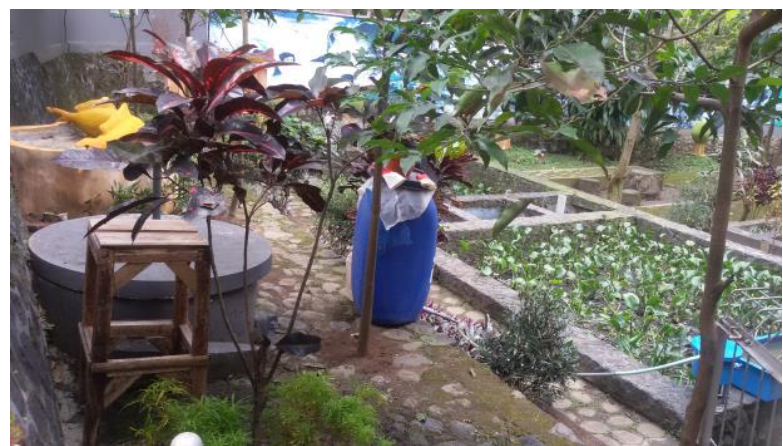

Figure 1. The Condition of IPAL Communal Tlogomas, Malang (2017)

This study intended to determine the optimal sand thickness for reducing wastewater turbidity, as well as the residence time required to produce clearer water output. The focus of this study is on changes of the turbidity level of the wastewater. Turbidity in water is due the contain of mud that consists of various suspended solids hence the water visually looks dirty. The materials that cause turbidity include sludge, organic matter, and suspended particles. The ultimate goal of this research is to improve the quality of domestic wastewater, which in this case is blackwater, so it can be reused for irrigation purposes. This will also help to reduce the pollution in the river.

\section{Literature Review}

Poor quality of an environment is mainly caused by the increased levels of pollution (Supradata, 2005). Mostly, wastewater discharged into the river is wastewater from domestic activities. Without any treatment, this will affect the sustainability of the ecosystem. Approximately, 50-75\% of the organic load in the river comes from domestic wastes (Nelwan, 2003). The contaminated raw water sources will lead to the emergence of various diseases, especially related to the digestive tract and respiration organs.

Wastewater that pollutes the environment is mainly domestic waste derived from household activities, such as bathing, laundry, toilet and cooking (Gosch, 1998). Domestic wastewater is subdivided into two, namely wastewater derived from the toilet or known as blackwater, and wastewater from kitchens and bathrooms, which is known as greywater (Lange and Otterpohl, 1997). Domestic wastewater generally comes from toilets $(33.3 \%)$, bath activities $(33.33 \%)$ and the rest comes from laundry and cleaning, drink and clothing activities. Domestic wastewater consists of carbohydrates, fats, proteins, urea, phosphate, salts, bacteria and heavy metals (Bablo and Wach, 1992). Household waste primarily contains organic substances, thus a simple processing method is arguably enough to remove the pollutants (Gintings, 1992).

Wastewater management aims to reduce or eliminate pollutants, either pathogenic microorganisms, chemicals, or radioactive (MOH, 1990). In Lismore (2010), it is explained that the water purification process is carried out through the following process: 


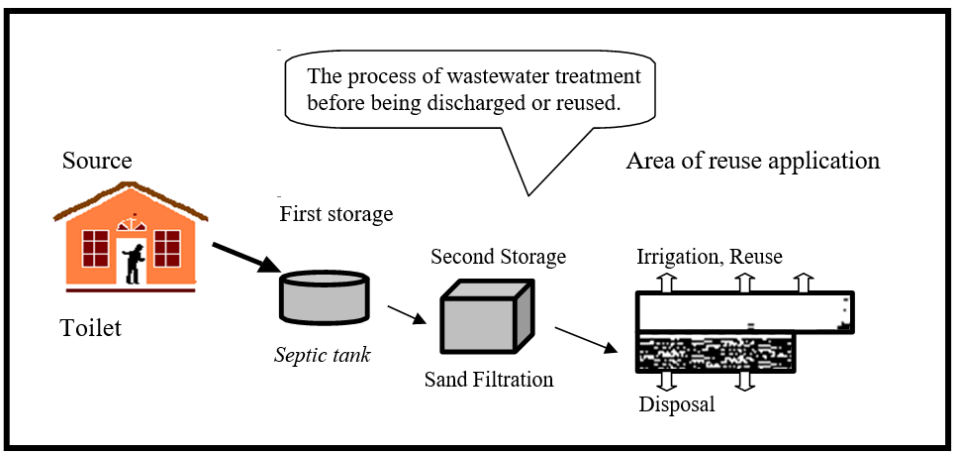

Figure 2. The Process of wastewater purification (Lismore, 2010)

The picture explains that filtration method using sand material is applied for filtering wastewater that mainly comes from the toilet. In addition, previous studies revealed that sand is a potential material for water purification. This has been studied by Adhibaswara et al. (2011), Sodamage and Pearse (2013), and other researchers. The treatment aims to reduce the level of pollutants and organic matter in wastewater before being discharged into rivers or being reused for another purpose. In addition, the treated water can also be reused as irrigation water for agricultural activities.

\section{Method}

This research applied the single filtration method to process domestic wastewater (blackwater) obtained from the communal septic tank. The method was intended to produce clearer water output. Data were collected directly in the field during the experiment by measuring the level of turbidity (NTU) of wastewater.

\section{Research location}

This research was conducted at the Waste Water Treatment Plant (IPAL) Communal of Tlogomas, Malang City.

\section{Materials}

The main instruments of this research were wastewater container, filter box, pipe, and Nephelometer, for measuring turbidity level in NTU (Nephelometric Turbidity Unit). The materials used were domestic wastewater (blackwater) obtained directly from communal septic tank at IPAL Tlogomas, as well as concrete sand as the filter material.

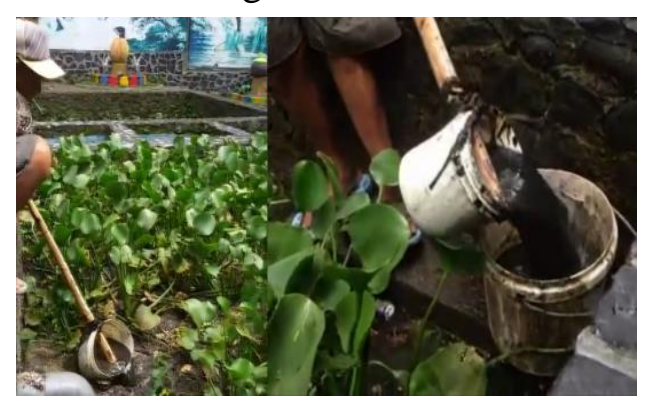

Figure 3. Blackwater

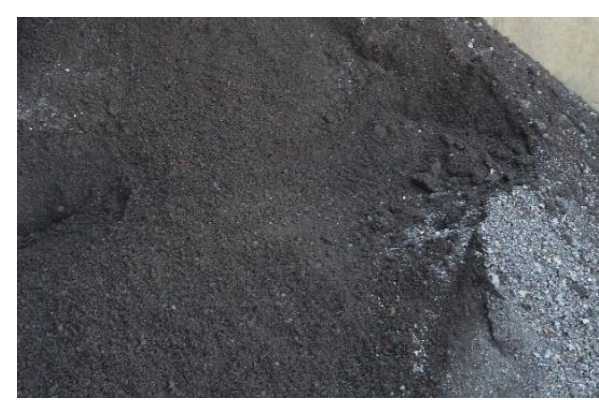

Figure 4. Concrete Sand

Concrete sand is the sand obtained from the crater of mountain or stream, which has the following characteristics:

1. having black color

2. rough, hard and sharp, with the size of 0.075 to $5.0 \mathrm{~mm}$

3. slightly contain sludge, but not exceeding $4 \%$. 


\section{Filter Box Designing}

The physical model of the experiment was made on the lab scale. The filter box was $25 \mathrm{x}$ $60 \mathrm{~cm}$ and filled with concrete sand with the thickness variations $(10 \mathrm{~cm}, 15 \mathrm{~cm}$, and 20 $\mathrm{cm})$. The filter layer was designed in the best possible position and washed before used in order to remove the sludge.

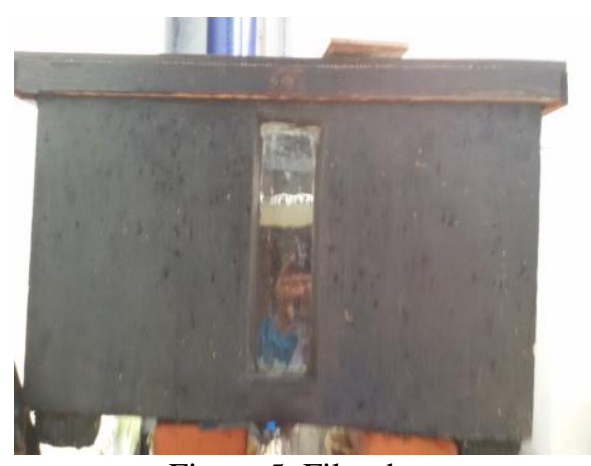

Figure 5. Filter box

\section{$\underline{\text { Research Procedures }}$}

The experiments in this study were conducted through the following steps:

1. Instruments preparation

2. Collection of blackwater from the communal septic tank.

3. Filling the wastewater container storage with blackwater.

4. Measuring the initial turbidity of each blackwater sample (morning and afternoon) before the experiment.

5. Connecting the wastewater container with the filter the filter box.

6. Measuring the turbidity of processed blackwater.

7. Repeating the procedures based on the retention times.

The process of experimental activities in this study is also explained by the following flowchart:

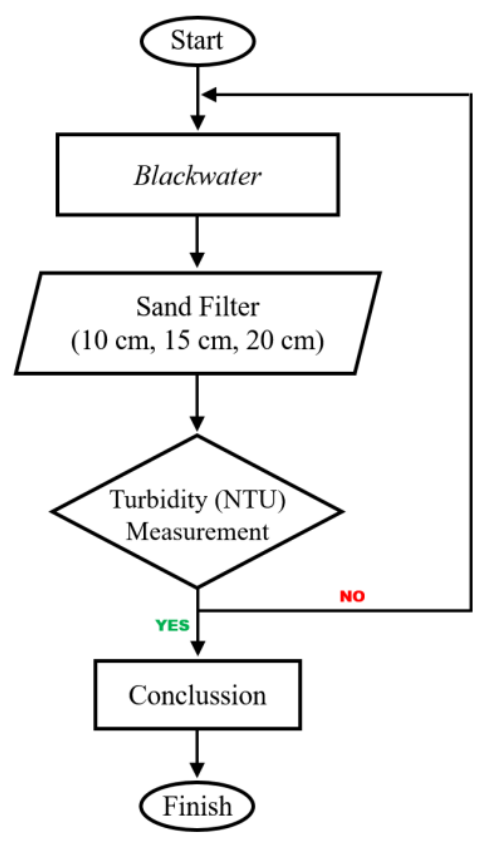

Figure 6. Research Mechanism 


\section{Data Analysis}

Research data were analyzed by using the descriptive method to know the decrease of turbidity level of the blackwater. Furthermore, the inferential statistical analysis was performed using Linear Regression in order to determine the effect of sand thickness treatment on the level of wastewater turbidity. The software for data analysis was SPSS 21 on Windows operating system.

\section{Results and Discussion}

Treatment 1 (Sand filter $10 \mathrm{~cm}$ )

The following data show the results of turbidity measurement of the blackwater treated with sand filter $10 \mathrm{~cm}$ :

Table 1. Data of blackwater turbidity during treatment 1

\begin{tabular}{ccccc}
\hline \multirow{2}{*}{ No } & \multicolumn{2}{c}{ Turbidity (NTU) } & $\begin{array}{c}\text { HRT } \\
\text { (Day) }\end{array}$ & $\begin{array}{c}\text { Grade 1 } \\
\text { Standard }\end{array}$ \\
\cline { 2 - 5 } & Morning & Afternoon & & \\
\hline 1 & 1000 & 800 & 0 & \\
2 & 650 & 605 & 1 & \\
3 & 560 & 530 & 2 & \\
4 & 430 & 410 & 3 & \\
5 & 380 & 360 & 4 & \\
6 & 345 & 325 & 5 & \\
7 & 300 & 295 & 6 & \\
8 & 285 & 270 & 7 & \\
9 & 270 & 260 & 8 & \\
10 & 275 & 255 & 9 & \\
\hline
\end{tabular}

Source: Research data (2017)

Based on Table 1, it can be seen that the initial turbidity of blackwater before the treatment was 1000 NTU (morning sample) and 800 NTU (afternoon sample). The data demonstrated that the level of turbidity tends to decrease from retention time day- 1 to day9. The final level of the morning and evening blackwater sample were 275 and 255 NTU, respectively. Therefore, it can be said that retention time longer that 9 days can result in the better out.

Treatment 2 (Sand Filter $15 \mathrm{~cm}$ )

The result of turbidity measurement of wastewater treated with sand filter $15 \mathrm{~cm}$ is described in this following table:

Table 2. Data of blackwater turbidity during treatment 2

\begin{tabular}{ccccc}
\hline \multirow{2}{*}{ No } & \multicolumn{2}{c}{ Turbidity (NTU) } & $\begin{array}{c}\text { HRT } \\
\text { (Day) }\end{array}$ & $\begin{array}{c}\text { Grade 1 } \\
\text { Standard }\end{array}$ \\
\cline { 2 - 5 } & Morning & Afternoon & & \\
\hline 1 & 1000 & 800 & 0 & \\
2 & 328 & 400 & 1 & \\
3 & 300 & 360 & 2 & \\
4 & 250 & 300 & 3 & \\
5 & 200 & 270 & 4 & \\
6 & 170 & 240 & 5 & \\
7 & 150 & 210 & 6 & \\
8 & 140 & 195 & 7 & \\
9 & 130 & 180 & 8 & \\
10 & 120 & 170 & 9 & \\
\hline
\end{tabular}

Source: Research Data (2017) 
In line with the previous treatment, the results of treatment 2 showed that the turbidity of blackwater continues to decrease with the longer retention time. On the longer retention time, the $9^{\text {th }}$ day, the level of turbidity of blackwater taken in the morning was 120 NTU, and the blackwater taken in the afternoon was 170 NTU.

Treatment 3 (Sand Filter $20 \mathrm{~cm}$ )

Table 3 presents the results of the turbidity measurement of the blackwater treated with sand thickness of $20 \mathrm{~cm}$.

Table 3. Data of blackwater turbidity during treatment 3

\begin{tabular}{ccccc}
\hline \multirow{2}{*}{ No } & \multicolumn{2}{c}{ Turbidity (NTU) } & $\begin{array}{c}\text { HRT } \\
\text { (Day) }\end{array}$ & $\begin{array}{c}\text { Grade 1 } \\
\text { Standard }\end{array}$ \\
\cline { 2 - 3 } 1 & Morning & Afternoon & 0 & \\
2 & 1000 & 800 & 1 & \\
3 & 300 & 320 & 2 & \\
4 & 250 & 280 & 3 & \\
5 & 200 & 230 & 4 & \\
6 & 180 & 200 & 5 & \\
7 & 150 & 175 & 6 & \\
8 & 130 & 155 & 7 & \\
9 & 100 & 120 & 8 & \\
10 & 95 & 110 & 9 & \\
\hline
\end{tabular}

Source: Research Data (2017)

Based on table 3, it can be seen that treatment 3 (sand filter $20 \mathrm{~cm}$ ) was the most optimal treatment in reducing the turbidity of blackwater. This is indicated by the final turbidity levels on the retention time of day-9, which were 90 NTU for morning blackwater sample, and 105 NTU for afternoon blackwater sample. This result was the lowest result when compared with the other treatment.

\section{$\underline{\text { Statistical Analysis }}$}

1. Morning Blackwater Sample

The results of the Linear Regression analysis on the data of the turbidity level of morning blackwater sample is presented in Table 4. This result will explain the effect of sand filter treatment on the turbidity of wastewater.

Table 4. The result of regression analysis on morning sample

\begin{tabular}{ccccc}
\hline Independent variable & Coefficient & $\boldsymbol{p}$-value & $\mathbf{R}^{\mathbf{2}}$ & Equation \\
\hline Sand thickness & -11.847 & 0.126 & $8.1 \%$ & $\mathrm{Y}=523.386-11.847 \mathrm{X}+\mathrm{e}$ \\
\hline Source:
\end{tabular}

Source: Research data (2018)

The result of Linear Regression analysis between sand thickness and turbidity in morning blackwater sample data showed a regression coefficient of $-11,847$, with significance value $0,126(>\alpha 0,05)$. Thus, it can be stated that the thickness of the sand has a negative and non-significant effect on the turbidity of treated wastewater. In other words, the thicker the sand layer used for filtration, the turbidity of wastewater treated will be lower. The determination coefficient obtained from the Regression analysis was $8.1 \%$. This represents the influence of sand thickness treatment applied to the effluent level of the treated wastewater. As for the rest (91.9\%) is the percentage of the influence of other variables or factors that are not applied or studied in this research. 


\section{Afternoon Blackwater Sample}

The results of Linear Regression analysis between sand thickness treatment and turbidity of wastewater obtained in the afternoon can be seen in the following table:

Table 5.The result of regression analysis on afternoon sample

\begin{tabular}{ccccc}
\hline Independent variable & Coefficient & $\boldsymbol{p}$-value & $\mathbf{R}^{\mathbf{2}}$ & Equation \\
\hline Sand thickness & -10.129 & 0.079 & $10.6 \%$ & $\mathrm{Y}=493.143-10.129 \mathrm{X}+\mathrm{e}$ \\
\hline
\end{tabular}

Source: Research data (2018)

The summary of Linear Regression result showed that the data of afternoon blackwater sample had a regression coefficient of -10.129 , with a significance value of $0.079(>\alpha$ $0.05)$. Thus, the interpretation is similar to the analysis result of morning blackwater data. Statistically, sand thickness treatment had a negative and non-significant effect on the turbidity of wastewater. The thicker the sand layer, the level of turbidity will be more decreased. Regarding the coefficient of determination, the percentage of sand thickness influence on wastewater turbidity was $10.6 \%$. In other words, the remaining $89.4 \%$ represents the influence of other variables or factors, apart from the applied treatment.

\section{Discussion}

The use of concrete sand as a filter material is one of the wastewater treatment solutions that is easy to apply even by the general community. The main reason is due to the ease in obtaining the material and the simplicity of the filter device. In theory, it is said that sand has a promising potential for water purification, whether by the method of quick sand filtration or slow sand filtration. Blackwater contains a high level of organic materials, so it tends to be muddy and visually dark. In this case, the use of sand is very appropriate to filter out the mud load and reduce the turbidity of the wastewater.

Based on the measurement of the turbidity level during processing, it can be seen that the turbidity of wastewater is decreasing along with the increase of sand thickness and the addition of retention time. When compared between all the three treatments (sand filter 10 $\mathrm{cm}, 15 \mathrm{~cm}$ and $20 \mathrm{~cm}$ ), it can be stated that sand filter $25 \mathrm{~cm}$ is the most optimal treatment in lowering the turbidity of the wastewater. This finding is indicated by the final turbidity level of morning blackwater sample (90 NTU). Descriptively, if the sand filter applied is thicker, it will be more potential in reducing the turbidity of wastewater.

The results of linear regression analysis confirm what is described in the descriptive analysis. In both morning and afternoon blackwater samples, it is found that each has a negative coefficient and non-significant influence. Similar to the previous description, the thicker the sand filter, the better it is to filter the suspended solids contained in the wastewater. In other words, the filter is assessed to be more potential in filtering the sludge and other loads so the output water will have low turbidity.

According to Dubey and Omprakash (2013), the method of filtering wastewater using sand is one of the traditional methods that can be used as an alternative. Sand filters can be used to treat domestic wastewater into water that is suitable for agricultural activities. Furthermore, Gusdi et al. (2015) added that in wastewater treatment method by the filtration system, the sand layer should be the thickest layer, compared to the ratio of other materials. It is said that sand is able to purify the water optimally, the thicker the sand layer, the clearer the output water. Referring to the research of Adhibaswara et al. (2011), the sand layer is used to filter the mud and other materials contained in wastewater.

This result of this study is supporting the study conducted by Dewi and Yanti (2016), in which they used several filter materials, including sand, to reduce COD and TSS in tofu wastewater. In the research, the sand filter with $7 \mathrm{~cm}$ thickness can reduce the suspended 
solids optimally. TSS is a parameter closely related to turbidity, where the turbidity itself is the result of the suspended solids contained in wastewater. Therefore, it can be stated that the results of this study are in line with previous theories and studies. The sufficient sand thickness and retention time in the filtration process will produce clear water output.

\section{Conclusion}

Based on the result of this research, it can be concluded that: first, Sand can be used as filter material. The most optimal sand thickness for reducing the wastewater turbidity is 20 $\mathrm{cm}$. Second, The level of turbidity of wastewater is decreasing as the longer retention time is applied. The optimum retention time in reducing the turbidity is 9 days (80\%).

\section{References}

Adhibaswara, B., Indah, P. Rini, Muhammad Nico, \& Zara, M. 2011. Pengelolaan Air Secara Ekonomis dengan Penggunaan Tanggul Batang Kelapa Serta Penjernih Air Alami. Proceeding PESAT (Psikologi, Ekonomi, Sastra, Arsitektur \& Sipil). Vol.4. ISSN 1858-2559.

Bahlo, K., and Wach, G. 1992. Naturnahe Abwasserreinigung: Plannung and Bau Von Pflanzenklaranlagen. Okobuch, Kassel.

Departemen Kesehatan. 1990. Peraturan Menteri Kesehatan No.416/MENKES /PER/IX/1990 tentang Syarat-syarat dan Pengawasan Kualitas Air. Jakarta.

Dewi, Y. Sapta, \& Yanti, Buchori. 2016. Penurunan COD, TSS Pada Penyaringan Air Limbah Tahu Menggunakan Media Kombinasi Pasir Kuarsa, Karbon Aktif, Sekam Padi dan Zeolit. Jurnal Ilmiah Satya Negara Indonesia, Vo.9 No.1 (2016) 74-80.

Dubey, A. Kumar, \& Omprakash, Sahu. 2014. Review on Natural Methods for Wastewater Treatment. Journal of Urban and Environmental Engineering. Vol.8, No.1, (2014) 89-97.

Gintings, Perdana. 1992. Mencegah dan Mengendalikan Pencemaran Industri. Pustaka Sinar Harapan. Jakarta.

Gusdi, R., Hasnah, W., \& Uci, Septiana. 2015. Pembuatan Alat Penyaringan Air Sederhana dengan Metode Fisika. Jurnal Nasional Ecopedon. Vol.4, No.1, (2017) 19-21.

Gosch. 1998. Arbeitsunterlag. Siedlungswirschaft II. FH Giessen Friedberg.

Lange, J, dan Otterpohl, R. 1997. Abwasser Handbuch zu einer Zukunftlfahogen Wasserwirschaft Malbeton Verlag, Germany.

Lismore City Council. 2003. The Use of Reed Beds for the Treatment of Sewage \& Wastewater from Domestic Households.Department of Local Government's Septic Safe Program. New South Wales, Australia.

Mukhtasor. 2007. Pencemaran Pesisir dan Laut. PT. Pradnya Paramita. Jakarta.

Nelwan, F., Kawik, S., \& Budi, Kamulyan. 2003. Kajian Program Pengelolaan Air Limbah Perkotaan. Studi Kasus Pengelolaan IPAL Margasari Balikpapan. Jurnal Manusia dan Lingkungan, Vol. X, No. 2, (2003) 94-103.

Sodamade, G.A, and Pearse, L.F. (2013). Removal of Iron and Manganese Using Rapid Sand Filtration. NSE Technical Transaction, Vol.47, No.3.

Supradata. 2005. Pengolahan Limbah Domestik Menggunakan Tanaman Hias Cyperus alternifolius, L. dalam Sistem Lahan Basah Buatan Aliran Bawah Permukaan (SSFWetlands). Thesis unpublished. Magister Ilmu Lingkungan. Universitas Diponegoro, Semarang. 